\title{
Peralihan Hak Milik Tanah Waris Dalam Hukum Islam
}

\author{
Siti Maghfirotun Ni'mah \\ rotun.fhunair@gmail.com \\ Universitas Airlangga
}

\begin{abstract}
The transfer of inheritance rights can occur because inheritance is based on no will and / or in the presence of a legal act of transferring rights. Inheritance based on a will can be interpreted as the transfer of land rights from the rights holder to another party because the rights holder dies. This is usually called inheritance. Heritage assets as mentioned in Article 171 letter (e) Compilation of Islamic Law, namely inheritance is inherited property plus part of joint assets after being used for the needs of the testator during illness until death, tajhiz fees, debt payments and gifts for relatives. The issue discussed in this paper is related to the validity of the transfer of land rights due to inheritance in Islamic law and its legal consequences. Journal writing is classified as normative legal research to find legal rules, legal principles and relevant legal doctrines and Research method used in this research is normative law with statue approach, conceptual approach, and case study.

Keywords: Shifting Possessions; Land Certificate; Heirs.
\end{abstract}

\begin{abstract}
Abstrak
Peralihan hak milik tanah waris dapat terjadi karena pewarisan yang di dasari tanpa wasiat dan/atau dengan adanya sebuah perbuatan hukum pemindahan hak. Pewarisan yang di dasari tanpa wasiat dapat dimaknai sebagai berpindahnya hak atas tanah dari pemegang hak kepada pihak lain karena pemegang haknya meninggal dunia. Hal tersebut biasa disebut dengan pewarisan. Harta warisan sebagaimana disebutkan dalam Pasal 171 huruf (e) Kompilasi Hukum Islam yakni harta warisan merupakan harta bawaan ditambah bagian dari harta bersama setelah digunakan untuk keperluan pewaris selama sakit sampai meninggalnya, biaya pengurusan jenazah (tajhiz), pembayaran utang serta pemberian untuk kerabat. Isu yang dibahas pada tulisan ini adalah terkait keabsahan peralihan hak milik atas tanah akibat pewarisan dalam hukum Islam dan Akibat Hukumnya penulisan jurnal ini tergolong sebegai penelitian hukum yang bersifat normatif untuk menemukan aturan hukum, prinsip hukum maupun doktrin hukum yang relevan serta menggunakan pendekatan UndangUndang (Statute Approach), pendekatan konsep (conceptual approach), dan pendekatan studi kasus (case study).
\end{abstract}

Kata Kunci: Peralihan Hak Milik; Sertipikat Tamah; Ahli Waris.

\section{Pendahuluan}

Sengketa waris dapat terjadi apabila terdapat ketiadaan dan/atau ketidakjelasan aturan dalam menyelesaikan permasalahan waris. Sengketa yang terjadi akan dapat menimbulkan pertengkaran bahkan jika tidak segera dipecahkan akan terjadi tindakan saling membunuh antar ahli waris. ${ }^{1}$

\footnotetext{
${ }^{1}$ Komaruddin, 'Beragam Norma Dalam Penerapan Waris' (2013) 13 Jurnal Al Risalah.[22].
} 
Hukum waris ditujukan untuk mengatur tata cara pembagian harta peninggalan agar dapat bermanfaat kepada ahli waris dan/atau bagi para pihak yang ditinggalkan secara adil dan baik. Agar hal tersebut tidak menimbulkan permasalahan hukum kemudian. $^{2}$ Tujuan yang demikian ini memiliki makna bahwasannya harta peninggalan merupakan harta dan/atau hak milik dari pewaris yang di dapat melalui usahanya sendiri ataupun di dapatkan karena dirinya merupakan ahli waris. Hal tersebut agar ahli waris dapat dibenarkan secara sah di mata agama dan hukum bernegara. Demikian pula tujuan dari adanya pewarisan ini agar para ahli waris dapat diperbolehkan memiliki harta peninggalan melalui tata cara yang sah dan dibenarkan secara adat, agama dan/atau melalui hukum bernegara. ${ }^{3}$ Hukum waris memiliki tempat yang amat penting dalam hukum Islam. Hal ini dikarenakan kewarisan merupakan suatu hal yang pasti dan akan dialami oleh setiap orang. Selain itu karena kewarisan menyangkut langsung dengan harta benda yang ditinggalkan apabila tidak diberikan aturan hukum yag pasti maka akan berdampak pada timbulnya sengketa antar ahli waris. ${ }^{4}$

Adapun keberlakuan sistem hukum waris di Indonesia diantaranya adalah sebagai berikut: ${ }^{5}$

a. Hukum Kewarisan Islam berlaku untuk produk Indonesia yang beragama Islam;

b. Hukum Kewarisan Barat (BW) berlaku pada penduduk yang menganut sistem hukum Barat;

c. Sedangkan Hukum Kewarisan Adat belaku bagi orang-orang yang menganut Hukum Adat. Hal tersebut sebagaimana dianut oleh sebagian besar masyarakat Indonesia yang tinggalnya jauh dari perkotaan.

Pemberian Hak Atas Tanah sebagaimana dimaksud dalam Pasal 1 ayat (8) Peraturan Menteri Agraria No. 9/1999 merupakan Penetapan Pemerintah yang memberikan suatu hak atas tanah negara, perpanjangan jangka waktu hak,

\footnotetext{
${ }^{2}$ Tamakarin, Asas-Asas Hukum Waris Menurut Tiga Sistem Hukum (Pioner 1987).[84].

3 ibid.[84].

${ }^{4}$ Ahmad Azhar Basyir, Hukum Waris Islam (UII Press 2001).[3].

${ }_{5}$ M Idris Ramulyo, Perbandingan Pelaksanaan Hukum Kewarisan Islam Dengan Kewarisan Menurut Kitab Undang-Undang Hukum Perdata (BW) (Sinar Grafika 2000).
} 
pembaharuan hak, perubahan hak, termasuk pemberian hak diatas tanah Hak Pengelolaan. ${ }^{6}$ Hukum kewarisan sebagaimana terdapat dalam Pasal 171 (a) Kompilasi Hukum Islam merupakan hukum yang mengatur tentang pemindahan hak pemilikan harta benda peninggalan (tirkah) pewaris, menentukan siapa-siapa yang berhak menjadi ahli waris dan berapa bagiannya masing-masing. Sebagaimana terdapat dalam kasus peralihan hak atas tanah akibat pewarisan yang menjadikan sertipikat hak atas tanah sebagai objek sengketa, sertipikat dapat dimaknai sebagai surat tanda bukti hak. Hal tersebut terdapat dalam pasal 1 angka 20 Peraturan Pemerintah Nomor 24 tahun 1997 tentang Pendaftaran Tanah (untuk selanjutnya disebut dengan PP Pendaftaran Tanah). Penerbitan sertipikat hak atas tanah harus melalui beberapa proses untuk mendapatkan hak yang legal. Dengan demikian apabila proses perolehan sertipikat hak atas tanah tidak sesuai dengan prosedur yang berlaku maka dapat disebut dengan sertipikat cacat hukum. ${ }^{7}$

Dalam beberapa literatur dapat dimaknai bahwa sertipikat cacat hukum merupakan sertipikat yang keliru pada saat penerbitannya. ${ }^{8}$ Keliru pada saat penerbitannya dapat bermula pada awal tahap administrasi hingga cacat kepemilikan. Suatu sertipikat hak atas tanah dikatakan sebagai cacat administrasi apabila melanggar ketentuan sebagaimana diatur dalam Pasal 107 Peraturan Menteri Agraria Nomor 9 tahun 1999. Sedangkan suatu sertipikat dikatakan cacat kepemilikan apabila sertipikat yang diterbitkan tidak pada kepemilikan yang sah. Hal ini dapat didasari karena proses pemilikan atau bahkan perolehan peralihan hak atas tanah dengan cara melawan hukum. ${ }^{9}$

Adapun contoh yang dimaksud dengan sertipikat cacat hukum diantaranya adalah sertipikat palsu. Yakni data pembuatan sertipikat yang digunakan adalah palsu atau dipalsukan, tanda tangan kepala kantor pertanahan kabupaten/kotamadya

\footnotetext{
${ }^{6}$ Peraturan Menteri Agraria Nomor 9 tahun 1999

7 Eddy Ruchiyat, Politik Pertanahan Sebelum Dan Sesudah Berlakunya UUPA UU No.5 Tahun 1960 (Alumni 1995).[185].

${ }^{8}$ Irene Eka Sihombing, Segi-Segi Hukum Tanah Nasional Dalam Pengadaan Tanah Untuk Pembangunan (Universitas Trisakti).[56].

9 Adrian Sutedi, Peralihan Hak Atas Tanah Dan Pendaftarannya (Sinar Grafika 2007).[101].
} 
dipalsukan, blanko yang digunakan untuk membuat sertipikat bukan merupakan yang dikeluarkan oleh BPN. Sebuah sertipikat dapat dikatakan palsu atau tidaknya berdasarkan atas buku tanah yang terdapat dalaml Kantor Pertanahan setempat. Hal demikian dapat diketahui bawa data yang ada pada sertipikat tidak sesuai dengan dengan data yang terdapat dalam buku tanah. ${ }^{10}$

Apabila terdapat adanya sertipikat Palsu pada sebuat Kantor Pertanahan sementara pihak BPN tidak memiliki wewenang untuk menyatakan bahwa sertipikat tersebut palsu atau bukan maka semestinya sertipikat tersebut diteliti dan di stempel dengan kalimat "Sertipikat ini bukan produk Badan Pertanahan Nasional”. Untuk kemudian dapat dilaporkan kepada pihak yang berwajib untuk dilakukan pengkajian dan penelitian lebih lanjut. ${ }^{11}$ Upaya preventif untuk meminimalisir keberadaan sertipikat palsu ini dengan cara meningkatkan ketelitian petugas yang berwenang dalam proses pembuatan serta penerbitan sertipikat.

Selain adanya sertipikat palsu, seringkali terdengar adanya sertipikat ganda atau overlapping. Dapat dikatakan demikian karena satu bidang tanah terurai dalam dua sertipikat yang berbeda. Hal seperti ini seringkali terjadi pada wilayah yang masih kosong, yang belum memiliki batas-batas yang jelas pada setiap sisinya. ${ }^{12}$

Sertipikat ganda dapat terjadi karena adanya kesalahan pada saat pengukuran. Bisa dikarenakan pemohon salah menunjukkan letak batasan wilayah atau bahkan pada saat yang bersamaan, wilayah tersebut belum terpetakan. Selain itu adanya pemalsuan alat bukti lainnya yang tidak sesuai dengan aturan yang berlaku juga dapat menyebabkan munculnya sertipikat ganda kepemilikan hak atas tanah.

Hal lain yang dapat menyebabkan kemunculan sertipikat ganda adalah dengan penerbitan sertipikat yang diperoleh karena pewarisan. Atas ketidaktahuan ahli waris telah dijual kepada pihak ketiga dan telah diterbitkan sertipikat atas

\footnotetext{
${ }^{10}$ Ali Achmad Chomzah, Hukum Pertanahan Seri Hukum Pertanahan I-Pemberian Hak Atas Tanah Negara Dan Seri Hukum Pertanahan II-Sertipikat Dan Permasaahannya (Prestasi Pustaka 2002).[122].

${ }^{11}$ ibid.[122]. [143-144].

A.P. Parlindungan, Komentar Atas Undang-Undang Pokok Agraria (Mandar Maju 1991).
} 
nama pembeli. Sedangkan disisi lain ahli warisnya memohonkan peralihan hak milik atas tanah yang sama sehingga mengakibatkan munculnya sertipikat ganda. Atau bahkan dapat terjadi karena sertipikat sebelumnya belum terpetakan sehingga muncul sertipikat atas tanah yang sama dalam beberapa versi.

Banyaknya ketidaktahuan masyarakat tentang undang-undang dan peraturan tentang pendaftaran tanah terkait prosedur pembuatan sertipikat tanah menjadikan kian maraknya penerbitan sertipikat ganda. Masyarakat belum begitu menyadari akan pentingnya sertipikat tanah sebelum terbentur dengan keadaan memaksa. Seringkali ketika pembagian warisan baru menyadari akan arti pentingnya kepemilikan sertipikat hak atas tanah. Pewarisan hak dapat dimaknai sebagai perpindahan hak milik atas tanah dari pewaris kepada ahli waris karena pemegang hak telah meninggal dunia. Dengan demikian maka hak tersebut berpindah kepada ahli waris yang ada. ${ }^{13}$

Adanya perpindahan hak dari pewaris kepada ahli waris yang dikarenakan adanya kematian dan peristiwa hukum tertentu maka yang beralih tidak hanya objeknya tetapi juga haknya. Apabila terdapat surat atau bahkan sertipikat tanah yang ditinggalkan maka sertipikat tanah tersebut juga turut berpindah. Sebagaimana terdapat dalam pasal 26 Undang-Undang Nomor 5 tahun 1960 tentang Peraturan Dasar Pokok-Pokok Agraria (untuk selanjutnya disebut dengan UUPA) bahwa pewarisan dapat terjadi karena ketentuan perundang-unangan atau bahkan karena adanya wasiat dari orang-orang yang telah mewariskan. ${ }^{14}$

Peralihan hak milik atas tanah merupakan kegiatan pemeliharaan data terkait pendaftaran tanah yang mewajibkan kepada pemegang haknya untuk mendaftarkan kepada Kantor Pertanahan Kabupaten/Kota setempat. ${ }^{15}$ Kemudian dari data yang ada dicatat dalam daftar Buku Tanah. Perubahan nama atau peralihan hak milik atas sertifikat tanah waris yang dilakukan $\mathrm{F}$ terhadap $\mathrm{T}$ sudah semestinya dilakukan.

\footnotetext{
${ }^{13}$ Boedi Harsono, Hukum Agraria Indonesia Sejarah Pembentukan Undang-Undang Pokok Agraria. Jumbatan (Jumbatan 2003).[128].

${ }^{14}$ Urip Santoso, Pendaftaran Dan Peralihan Hak Atas Tanah (Kencana 2011).[398].

${ }^{15}$ Beni Bosu, Perkembangan Terbaru Sertipikat (Tanah, Tanggungan Dan Condominium) (Mediatama Saptakarya 1997).[5].
} 
Hanya saja beberapa prosedur mengalami kesalahan terlebih $\mathrm{F}$ bukan merupakan ahli waris yang seharusnya menerima bagian dari harta bawaan atas perkawinan $\mathrm{N}$ dan U. Seharusnya yang berhak melakukan dan menerima peralihan hak milik sertifikat tanah waris atas tanah $\mathrm{N}$ dan $\mathrm{U}$ adalah kelima anak (A-E) karena $\mathrm{T}$ merupakan harta bersama dari orang tuanya.

Sebagaimana disebutkan dalam Pasal 1 angka 20 Peraturan Pemerintah Nomor 24 Tahun 1997 tentang pendaftaran tanah (untuk selanjutnya disebut PP Pendaftaran Tanah) sertipikat tanah merupakan surat tanda bukti hak sebagaimana dimaksud dalam Pasal 9 ayat (2) UUPA untuk hak atas tanah, hak pengelolaan, tanah wakaf, hak milik atas satuan rumah susun dan hak tanggungan yang masing-masing sudah dibukukan dalam buku tanah yang bersangkutan. Sebagaimana kasus yang dimiliki oleh ahli waris dari $\mathrm{N}$ dimana hak milik atas tanahnya beralih begitu saja sepeninggal pewaris tanpa diketahui oleh ahli waris lainnya. Untuk lebih jelasnya digambarkan dalam skema berikut:

\begin{tabular}{|c|c|c|}
\hline $\begin{array}{l}\text { NGATEMAN } \\
\text { Wafat } 8 \text { April } 2006\end{array}$ & $\begin{array}{c}\text { UMIYAH } \\
\text { Vafat 28 Juni } 1972\end{array}$ & $\begin{array}{c}\text { X SAMI } \\
\text { Menikah dengan } \\
\text { Ngateman } 5 \text { Des } 1972\end{array}$ \\
\hline Harta bersama & (saudara seayah) & \\
\hline
\end{tabular}

Skema 1: Keluarga Ngateman

Penjelasan Skema I:

Ngateman (N) menikah dengan Umiyah (U), dikaruniai 5 (lima) orang anak yakni A, B, C, D, E. Dalam perkawinan tersebut, $\mathrm{N}$ dan $\mathrm{U}$ memiliki harta bersama berupa sebidang tanah berlokasi di desa Bulurejo, Kecamatan Benjeng, Kabupaten Gresik yang di sertipikatkan dengan nomor register 00651 atas nama Ngateman. Pada tanggal 28 Juni 1972 U meninggal dunia. Tak lama berselang pada tanggal 5 Desember 1972 N menikah dengan Sami (S) dak dari perkawinan tersebut dikaruniai 1 (satu) orang anak yakni $\mathrm{F}$ sehingga jumlah anak yang dimiliki oleh $\mathrm{N}$ adalah 6 (enam) orang. 


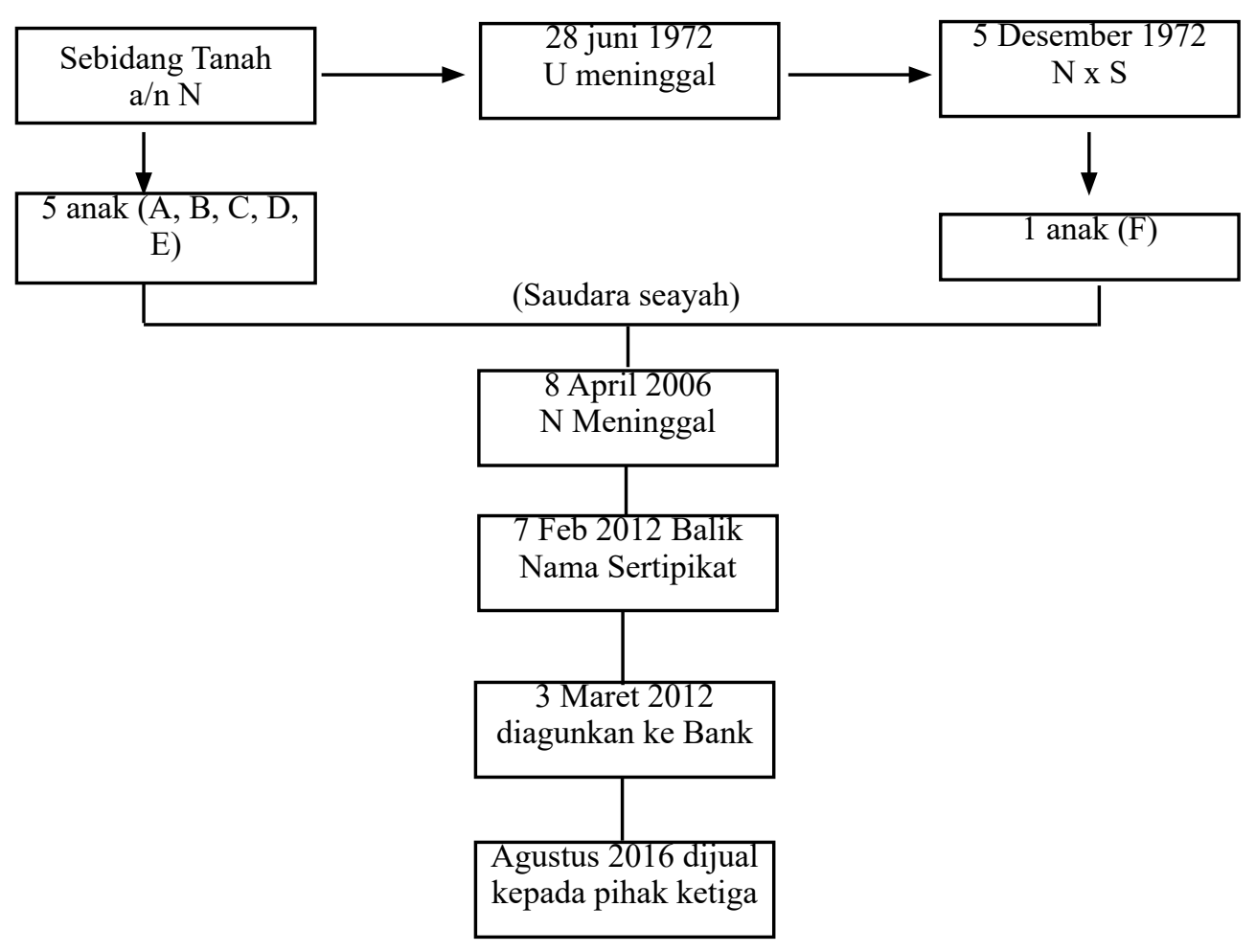

Skema 2: Kronologi Kasus

Penjelasan kronologi kasus:

1. Terdapat sebidang tanah hak milik ( $\mathrm{T}$ ) atas nama $\mathrm{N}$ yang diperoleh dari perkawinan selama dengan U berlokasi di desa Bulurejo, Kecamatan Benjeng, Kabupaten Gresik yang disertipikatkan dengan nomor register 00651 atas nama N;

2. Dari perkawinan tersebut $\mathrm{N}$ dikaruniai 5 (lima) orang anak yakni A, B, C, D, E ;

3. Pada tanggal 28 Juni 1972 U meninggal dunia;

4. Pada tanggal 5 Desember $1972 \mathrm{~N}$ menikah dengan S, dikaruniai 1 (satu) orang anak yakni $\mathrm{F}$ sehingga jumlah anak kandung dari $\mathrm{N}$ adalah 6 (enam) orang yakni A, B, C, D, E, F. Kedelapan anggota keluarga tersebut tinggal diatas T;

5. Pada tanggl 8 April $2006 \mathrm{~N}$ meninggal dunia dan para ahli waris sepakat untuk tidak pernah melakukan pewarisan terhadap $\mathrm{T}$ dengan pertimbangan $\mathrm{S}$ masih hidup dan tinggal diatas T. Sehingga $T$ tetap menjadi rumah induk bagi para ahli waris A, B, C, D, E;

6. Pada tanggal 7 Februari 2012 , F melakukan peralihan hak atas tanah tanpa sepengetahuan A, B, C, D, E sehingga nama pemegang hak yang terdapat dalam sertipikat tersebut bukan lagi atas nama $\mathrm{N}$ melainkan atas nama $\mathrm{S}$ dan/ atau F. Pada tanggal 3 Maret 2012 T diagunkan ke Bank tanpa sepengetahuan $\mathrm{A}, \mathrm{B}, \mathrm{C}, \mathrm{D}, \mathrm{E}$ oleh F;

7. Pada bulan Agustus $2016 \mathrm{~F}$ menjual $\mathrm{T}$ kepada pihak ketiga. Hal ini baru diketahui oleh A, B, C, D, E satu bulan setelah T berpindah tangan; 
Sebagaimana yang terjadi dalam kasus peralihan hak milik sertifikat tanah waris oleh F. Harta bersama yang menjadi objek sengketa merupakan hasil dari $\mathrm{N}$ dan $\mathrm{U}$ selama perkawinan, sehingga apabila diwariskan maka yang seharusnya menerima objek sengketa $(\mathrm{T})$ tersebut adalah kelima anak dari hasil perkawinan mereka. Tetapi setelah $\mathrm{N}$ menikah dengan $\mathrm{S}$, objek sengketa $(\mathrm{T})$ yang semestinya menjadi harta bawaan N kemudian diambil alih oleh F sepeninggal N. Seharusnya harta bawaan $\mathrm{N}$ tersebut bukan menjadi hak milik $\mathrm{S}$ dan $\mathrm{F}$ dikarenakan ahli waris dari $\mathrm{N}$ dan $\mathrm{U}$ masih ada. Harta bersama antara $\mathrm{N}$ dan $\mathrm{U}$ sudah semestinya jatuh kepada ahli warisnya apapun yang terjadi. Tetapi faktanya dapat beralih menjadi milik orang lain yang bukan termasuk sebagai ahli waris dari $\mathrm{N}$ dan $\mathrm{U}$.

Dalam Pasal 19 Ayat (2) huruf c UUPA dinyatakan bahwa akhir kegiatan pendaftaran tanah di seluruh wilayah Republik Indonesia yang diadakan oleh Pemerintah adalah pemberian surat-surat tanda bukti hak, yang berlaku sebagai alat pembuktian yang kuat. Namun demikian UUPA tidak menyebut apa nama suratsurat tanda bukti hak tersebut. ${ }^{16}$

Pasal 19 UUPA dilaksanakan oleh PP Pendaftaran Tanah. Dalam PP Pendaftaran Tanah tersebut disebutkan bahwa surat tanda bukti hak atas tanah yang didaftar dinamakan sertifikat. Menurut Pasal 13 Ayat 3 PP Pendaftaran Tanah yang dimaksud dengan sertipikat adalah salinan buku tanah dan surat ukur setelah dijahit menjadi satu bersama-sama dengan suatu kertas sampul yang bentuknya ditetapkan oleh Menteri Agraria.

Dalam PP Pendaftaran Tanah diatur 2 (dua) macam kegiatan pendaftaran tanah, yaitu pertama kegiatan pendaftaran tanah untuk pertama kalinya melalui pendaftaran tanah secara sistematik dan pendaftaran tanah secara sporadik, dan kedua pemeliharaan data pendaftaran tanah. ${ }^{17}$

Kegiatan pendaftaran tanah untuk pertama kalinya menghasilkan surat tanda bukti hak yang berupa sertipikat. Menurut Pasal 1 angka 20 PP Pendaftaran Tanah yang dimaksud dengan sertipikat adalah surat tanda bukti hak sebagaimana dimaksud

\footnotetext{
${ }^{16}$ Pasal 19 Ayat (2) huruf c UUPA

17 Santoso (n 14).,Op.Cit.[260].
} 
dalam Pasal 19 Ayat (2) huruf c UUPA untuk hak atas tanah, hak pengelolaan, tanah wakaf, hak milik atas satuan rumah susun dan hak tanggungan yang masing-masing sudah dibukukan dalam buku tanah yang bersangkutan.

Dikarenakan dalam kasus peralihan hak milik sertipikat tanah waris yang dilakukan oleh F tidak sebagaimana mestinya maka seharusnya sertipikat tersebut batal demi hukum atau dianggap tidak pernah ada, dinyatakan tidak berlaku serta ditarik dari peredaran. Hal tersebut dikarenakan objek sengketa (T) merupakan harta bersama yang dimiliki oleh $\mathrm{N}$ dan $\mathrm{U}$ selama perkawinannya, sehingga yang berhak menerima $\mathrm{T}$ adalah ahli waris dari perkawinan $\mathrm{N}$ dan $\mathrm{U}$ (dalam hal ini adala A-E). Tetapi fakta yang terjadi, sertipikat tanah tersebut dapat dengan mudah dibalik namakan oleh F. Sedangkan prosedur untuk balik nama sebagaimana dijelaskan dalam UUPA adalah mengenai syarat formal yang harus dilengkapi, diantaranya:

a. Sertipikat hak atas tanah atau Hak Milik atas nama pewaris, atau apabila mengenai tanah belum terdaftar, bukti pemilikan berupa selain sertipikat misalnya petuk pajak bumi, pajak hasil bumi, verponding Indonesia, kutipan letter c;

b. Surat kematian atas nama pemegang hak yang tercantum dalam sertipikat yang bersangkutan dari Kepala Desa/Kelurahan tempat tinggal pewaris waktu meninggal dunia, rumah sakit, petugas kesehatan, atau instansi yang berwenang;

c. Surat tanda bukti sebagai ahli waris. Hal ini yang dapat menjadi ganjalan atau dasar gugatan bagi A-E untuk mengambil kembali apa yang menjadi haknya. Apabila F menyatakan sebagai ahli waris dari N, maka tidak seharusnya menghilangkan asal-usul kelima anak $\mathrm{N}$ dari perkawinan sebelumnya. Menjadikan adanya indikasi mengenai itikad tidak baik yang dilakukan $\mathrm{F}$ terhadap A-E karena F kemudian mengambil alih harta bersama milik $\mathrm{N}$ dan $\mathrm{U}$ yang seharusnya diwariskan kepada A-E.

Sebagaimana terdapat dalam Pasal 171 (a) Kompilasi Hukum Islam yang mendefinisikan bahwa hukum kewarisan merupakan hukum yang mengatur tentang pemindahan hak pemilikan harta benda peninggalan (tirkah) pewaris, menentukan siapa-siapa yang berhak menjadi ahli waris dan berapa bagiannya masing-masing. 


\begin{tabular}{|c|c|c|c|c|c|}
\hline \multirow{2}{*}{$\begin{array}{c}\text { SEBAB/ } \\
\text { HUBUNGAN }\end{array}$} & \multirow{2}{*}{$\begin{array}{c}\text { AHLI } \\
\text { WARIS }\end{array}$} & \multirow[b]{2}{*}{ SYARAT } & \multirow{2}{*}{$\begin{array}{c}\text { PEROLEHAN } \\
\text { HARTA } \\
\text { WARIS }\end{array}$} & \multicolumn{2}{|c|}{ DASAR HUKUM } \\
\hline & & & & $\begin{array}{c}\text { AL } \\
\text { QURAN }\end{array}$ & KHI \\
\hline \multirow{4}{*}{$\begin{array}{l}\text { A. Perkawinan } \\
\text { (yang masih } \\
\text { terikat status) }\end{array}$} & & $\begin{array}{l}\text { Bila tidak ada } \\
\text { anak / cucu }\end{array}$ & $1 / 4$ & \multirow[b]{2}{*}{ An Nisa' 12} & \multirow[b]{2}{*}{180} \\
\hline & $\begin{array}{l}\text { Istri/ } \\
\text { Janda }\end{array}$ & $\begin{array}{l}\text { Bila ada anak/ } \\
\text { cucu }\end{array}$ & $1 / 8$ & & \\
\hline & \multirow{2}{*}{$\begin{array}{l}\text { Suami/ } \\
\text { Duda }\end{array}$} & $\begin{array}{l}\text { Bila tidak ada } \\
\text { anak / cucu }\end{array}$ & $1 / 2$ & \multirow[b]{2}{*}{ An Nisa' 12} & \multirow[b]{2}{*}{179} \\
\hline & & $\begin{array}{l}\text { Bila ada anak/ } \\
\text { cucu }\end{array}$ & $1 / 4$ & & \\
\hline \multirow{8}{*}{$\begin{array}{l}\text { B. Nasab/ } \\
\text { Hubungan } \\
\text { Darah }\end{array}$} & \multirow{2}{*}{$\begin{array}{c}\text { Anak } \\
\text { Perempuan }\end{array}$} & $\begin{array}{c}\text { Sendirian } \\
\text { (tidak ada anak } \\
\text { dan cucu lain) }\end{array}$ & $1 / 2$ & \multirow{5}{*}{ An Nisa’ 11} & \multirow{5}{*}{176} \\
\hline & & $\begin{array}{c}\text { Dua atau anak } \\
\text { perempuan } \\
\text { tidak ada anak } \\
\text { atau cucu laki-laki }\end{array}$ & $2 / 3$ & & \\
\hline & \multirow{3}{*}{$\begin{array}{c}\text { Anak } \\
\text { Laki-Laki }\end{array}$} & Sendirian & \multirow{3}{*}{$\begin{array}{c}\text { Ashobah (sisa } \\
\text { seluruh harta } \\
\text { setelah dibagi } \\
\text { pembagian lain) }\end{array}$} & & \\
\hline & & $\begin{array}{c}\text { atau Bersama anak } \\
\text { / cucu lain } \\
\text { (laki-laki / } \\
\text { perempuan) }\end{array}$ & & & \\
\hline & & $\begin{array}{c}\text { Pembagian antara } \\
\text { laki-laki dan } \\
\text { perempuan } 2: 1\end{array}$ & & & \\
\hline & \multirow{3}{*}{$\begin{array}{c}\text { Ayah } \\
\text { Kandung }\end{array}$} & $\begin{array}{l}\text { Bila tidak ada } \\
\text { anak / cucu }\end{array}$ & $1 / 3$ & \multirow{3}{*}{ An Nisa' 11} & \multirow{3}{*}{177} \\
\hline & & & & & \\
\hline & & $\begin{array}{l}\text { Bila ada anak / } \\
\text { cucu }\end{array}$ & $1 / 6$ & & \\
\hline
\end{tabular}




\section{Bila tidak ada anak / cucu dan tidak ada dua saudara atau lebih dan tidak Bersama Ayah Kandung \\ Bila ada anak /} cucu dan/ atau dua Ibu Kandung saudara atau lebih dan tidak Bersama Ayah Kandung Bila tidak ada anak / cucu dan tidak ada dua saudara atau lebih tetapi Bersama Ayah Kandung Sendirian tidak ada anak / cucu

Saudara laki-laki atau perempuan seibu

seibu

Saudara
perempuan
kandung atau
seayah

Saudara lakilaki kandung atau seayah dan tidak ada Ayah Kandung Dua orang lebih tidak ada anak / cucu dan tidak Sendirian tidak ada anak / cucu dan tidak ada Ayah Kandung Dua orang lebih tidak ada anak / cucu dan tidak ada Ayah Kandung

Sendirian atau Bersama saudara lain dan tidak ada anak / cucu dan tidak ada ayah kandung

Pembagian antara laki-laki dan perempuan $=2: 1$

Cucu/
keponakan
(anak
saudara)
tuanya yang menjadi ahli
1/3 dari sisa sesudah diambil istri/ janda atau suami / duda

$1 / 6$

$1 / 3$

$1 / 2$

An Nisa' 12 diganti

kedudukannya sebagai ahli waris ijtihad waris. Persyaratan berlaku sesuai kedudukan ahli waris yang diganti 
Dalam penjelasan Pasal 42 ayat (1) PP Pendaftaran Tanah disebutkan bahwa peralihan hak karena pewarisan yang berkaitan dengan bidang tanah yang sudah terdaftar wajib diserahkan oleh penerima hak kepada Kantor Pertanahan. Sedangan yang berkaitan dengan nama yang tercantum dalam sertipikat yang bersangkutan, namanya dicantumkan sebagai ahli waris. Pendaftaran peralihan hak atas tanah merupakan suatu hal yang diwajibkan. Hal tersebut guna memberikan Perlindungan hukum kepada ahli waris dan/atau para pihak sehingga tetap terjaga tertib tata usaha pendaftaran tanah. Surat tanda bukti bahwasannya seseorang tersebut adalah merupakan ahli waris dari pihak yang bersangkutan dapat berupa akta keterangan hak mewaris, surat penetapan ahli waris dan/atau bahkan surat keterangan ahli waris.

Peralihan hak melalui pewarisan dapat terjadi secara otomatis pada saat pewaris meninggal dunia. Hal tersebut akan menimbulkan perubahan pada data yuridis terkait dengan alas hak yang menjadi objek warisan. Perubahan peralihan hak atas tanah harus didaftarkan dan harus dilakukan apabila terjadi perubahan pada data fisik dan data yuridis. Hal tersebut dalam rangka memberikan perlindungan hukum kepada ahli waris dan demi ketertiban tata usaha pendaftaran tanah. ${ }^{18}$

Dokumen-Dokumen yang membuktikan adanya hak atas tanah pada pewarisan sebagaimana disebutkan dalam Pasal 39 ayat (1) PP Pendaftaran Tanah. Hal tersebut wajib diberikan karena pendaftaran peralihan haknya baru dapat dilakukan setelah dilaksanakan pendaftaran pertama kali hak yang bersangkutan atas nama yang mewariskan. Jika penerima warisan terdiri dari satu orang, pendaftaran peralihan haknya dilakukan kepada orang tersebut berdasarkan surat tanda bukti sebagai ahli waris yang bersangkutan, tetapi jika penerima warisan lebih dari satu orang dan waktu peralihan haknya tersebut didaftarkan disertai dengan akta pembagian waris yang memuat keterangan hak atas tanah.

Perubahan nama atau peralihan hak milik sertifikat tanah waris yang dilakukan F terhadap T sudah semestinya dilakukan. Hanya saja beberapa prosedur mengalami kesalahan terlebih $\mathrm{F}$ bukan merupakan ahli waris yang seharusnya menerima bagian

${ }^{18}$ Sihombing (n 8). 
dari harta bawaan atas perkawinan $\mathrm{N}$ dan $\mathrm{U}$. Yang berhak melakukan dan menerima peralihan hak milik sertifikat tanah waris atas tanah $\mathrm{N}$ dan $\mathrm{U}$ adalah kelima anak (A-E) karena T merupakan harta bersama dari orang tuanya.

Dikarenakan dalam kasus peralihan hak milik sertifikat tanah waris yang dilakukan oleh $\mathrm{F}$ tidak sebagaimana mestinya maka seharusnya sertifikat tersebut batal demi hukum atau dianggap tidak pernah ada, dinyatakan tidak berlaku serta ditarik dari peredaran. Hal tersebut dikarenakan objek sengketa (T) merupakan harta bersama yang dimiliki oleh $\mathrm{N}$ dan $\mathrm{U}$ selama perkawinannya, sehingga yang berhak menerima $\mathrm{T}$ adalah ahli waris dari perkawinan $\mathrm{N}$ dan $\mathrm{U}$ (dalam hal ini adala $\mathrm{A}-\mathrm{E}$ ). Tetapi fakta yang terjadi, sertifikat tanah tersebut dapat dengan mudah dibaliknamakan oleh F. Sedangkan prosedur untuk balik nama sebagaimana dijelaskan dalam UUPA adalah mengenai syarat formal yang harus dilengkapi, diantaranya:

a. Sertifikat hak atas tanah atau Hak Milik atas nama pewaris, atau apabila mengenai tanah belum terdaftar, bukti pemilikan berupa selain sertifikat misalnya petuk pajak bumi, pajak hasil bumi, verponding Indonesia, kutipan letter $\mathrm{c}$;

b. Surat kematian atas nama pemegang hak yang tercantum dalam sertifikat yang bersangkutan dari Kepala Desa/Kelurahan tempat tinggal pewaris waktu meninggal dunia, rumah sakit, petugas kesehatan, atau instansi yang berwenang;

c. Surat tanda bukti sebagai ahli waris. Hal ini yang dapat menjadi ganjalan atau dasar gugatan bagi A-E untuk mengambil kembali apa yang menjadi haknya. Apabila F menyatakan sebagai ahli waris dari N, maka tidak seharusnya menghilangkan asal-usul kelima anak $\mathrm{N}$ dari perkawinan sebelumnya. Menjadikan adanya indikasi mengenai itikad tidak baik yang dilakukan $\mathrm{F}$ terhadap A-E karena F kemudian mengambil alih harta bersama milik $\mathrm{N}$ dan $\mathrm{U}$ yang seharusnya diwariskan kepada A-E.

Dikarenakan dalam kasus peralihan hak milik sertifikat tanah waris yang dilakukan oleh $\mathrm{F}$ tidak sebagaimana mestinya maka seharusnya sertifikat tersebut batal demi hukum atau dianggap tidak pernah ada, dinyatakan tidak berlaku serta 
ditarik dari peredaran. Hal tersebut dikarenakan objek sengketa (T) merupakan harta bersama yang dimiliki oleh $\mathrm{N}$ dan $\mathrm{U}$ selama perkawinannya, sehingga yang berhak menerima $\mathrm{T}$ adalah ahli waris dari perkawinan $\mathrm{N}$ dan $\mathrm{U}$ (dalam hal ini adala A-E). Tetapi fakta yang terjadi, sertifikat tanah tersebut dapat dengan mudah dibaliknamakan oleh F.

\section{Kesimpulan}

Peralihan hak milik atas tanah akibat pewarisan dalam Hukum Islam memiliki perhitungan sesuai dengan ketentuan agama. Peralihan hak milik atas sertipikat tanah yang dilakukan oleh seorang ahli waris tanpa sepengetahuan dari ahli waris lainnya sehingga dengan sengaja menghilangkan asal-usul dan/atau jumlah ahli waris yang ada dapat dikategorikan sebagai tindakan melawan hukum yang tidak dibenarkan secara prosedural serta tidak dibenarkan dari segi agama.

Keabsahan peralihan hak milik atas tanah akibat pewarisan yang tidak sesuai dengan prosedur dapat adalah batal demi hukum dan dianggap tidak pernah ada. Hal tersebut bermakna tetap diberlakukan sertipikat lama yang diterbitkan sebelum sepeninggal pewaris sehingga sertipikat yang baru diterbitkan dinyatakan tidak berlaku dan dapat ditarik dari peredaran. Dengan demikian maka tujuan awal dari pendaftaran peralihan sertipikat tanah dapat diarahkan kembali untuk memberikan rasa aman dan kepastian hukum sehingga tidak ada pihak yang dirugikan.

\section{Daftar Bacaan}

\section{Buku}

A.P. Parlindungan, Komentar Atas Undang-Undang Pokok Agraria (Mandar Maju 1991).

Adrian Sutedi, Peralihan Hak Atas Tanah Dan Pendaftarannya (Sinar Grafika 2007).

Ahmad Azhar Basyir, Hukum Waris Islam (UII Press 2001).

Bosu B, Perkembangan Terbaru Sertipikat (Tanah, Tanggungan Dan Condominium) (Mediatama Saptakarya 1997). 
Chomzah AA, Hukum Pertanahan Seri Hukum Pertanahan I-Pemberian Hak Atas Tanah Negara Dan Seri Hukum Pertanahan II-Sertipikat Dan Permasaahannya (Prestasi Pustaka 2002).

Harsono B, Hukum Agraria Indonesia Sejarah Pembentukan Undang-Undang Pokok Agraria. Jumbatan, Jakarta, 2003 (Jumbatan 2003).

Ramulyo MI, Perbandingan Pelaksanaan Hukum Kewarisan Islam Dengan Kewarisan Menurut Kitab Undang-Undang Hukum Perdata (BW) (Sinar Grafika 2000).

Ruchiyat E, Politik Pertanahan Sebelum Dan Sesudah Berlakunya UUPA UU No.5 Tahun 1960 (Alumni 1995).

Santoso U, Pendaftaran Dan Peralihan Hak Atas Tanah (Kencana 2011).

Sihombing IE, Segi-Segi Hukum Tanah Nasional Dalam Pengadaan Tanah Untuk Pembangunan (Universitas Trisakti).

Tamakarin, Asas-Asas Hukum Waris Menurut Tiga Sistem Hukum (Pioner 1987).

\section{Perundang-undangan}

Undang-Undang Dasar tahun 1945

Kitab Undang-Undang Hukum Perdata (Burgerlijk Wetboek)

UndangUndang Nomor 5 tahun 1960 tentang Perubahan Dasar Pokok-Pokok Agraria, Lembaran Negara Republik Indonesia Nomor 104 tahun 1960, Tambahan Lembaran Negara Nomor 2043.

Peraturan Pemerintah Nomor 24 tahun 1997 tentang Pendaftaran Tanah, Lembaran Negara Republik Indonesia Nomor 59 tahun 1997, Tambahan Lembaran Negara Nomor 3696.

Peraturan Menteri Negara Agraria/KBPN No.9/1999 tentang Tata Cara Pemberian dan Pembatalan Hak Milik Atas Tanah Negara dan Hak Pengelolaan.

\section{Jurnal}

Komaruddin, 'Beragam Norma Dalam Penerapan Waris' (2013) 13 Jurnal Al Risalah. 
--Halaman ini sengaja dikosongkan-- 